\title{
On the Cultivation of College Students' Constitutional Consciousness
}

\author{
Le Gao \\ College of Marxism, Jilin Agricultural University, Changchun 130118,China
}

\begin{abstract}
Keywords: College students; Constitutional consciousness; Rule of law; Cultivation; Way
\end{abstract}
\begin{abstract}
College students are the master and the future of China and the backbone of China's modernization drive. The cultivation of contemporary college students' constitutional consciousness is related to not only their own development, but also the progress of China's modernization and future development of the country and the nation. However, at present, college students do not have enough understanding of the constitution with quite weak constitutional consciousness, so colleges and universities should attach importance to the cultivation and education of college students' constitutional consciousness and give full play to the autonomy of college students in studying the constitution.
\end{abstract}

\section{Introduction}

Constitution is the fundamental law of a country and constitutional education is the core of legal education. In order to enhance the consciousness of law, the first step is to strengthen the constitutional consciousness and constantly strengthen education of college students' constitutional consciousness. College period is a key period for college students to develop the outlook on the world, life and value as well as a key period to cultivate citizen consciousness, so we should focus on cultivating and strengthening college students' constitutional consciousness and make them realize the important significance of a good constitutional consciousness on their own personality and a country's legal construction so as to make them truly adhere to the constitution, advocate it and have the belief in constitution. [1] Therefore, it is an important task for the moral education of higher education in our country in the new century to analyze problems in cultivating college students' constitutional consciousness, fully understand the importance of cultivating college students' constitutional consciousness and take corresponding positive measures.

\section{The Status Quo of Contemporary College Students' Constitutional Consciousness}

Although college students have mastered the basic contents of constitutional knowledge, because their constitutional concept is obsolete and their understanding of constitutional consciousness' core contents, the functions of Constitution, the implementation and evaluation of Constitution, their constitutional awareness still remains to be further improved. [2]

The Level of College Students' Awareness of the Constitution is Low. College students do not accept the system of constitutional education with less knowledge of constitutional knowledge and low interest. The mastery of constitutional knowledge is the prerequisite for the formation of constitutional consciousness. Constitution is relatively detached with strong adjustment force like the civil law and criminal law, so it cannot give people direct economic benefits. In colleges and universities, in order to get a high salary after graduation, students of law majors are often prone to study civil law, economic law, international economic law and other popular courses, and little love to study the constitution. While non-law students are more focused on the professional knowledge of their own majors with less contact with the Constitution, and they can only get some sporadic understanding through the basic course of law. [3] In such an environment, college students have never had the opportunity to obtain systematic constitutional education, which is clearly not conducive to their formation of the correct constitutional consciousness.

Influence of Traditional Culture. Due to the influence of traditional culture, college students 
have poor constitutional awareness of rights. China has a history of more than two thousand years of feudal society, and the political monarchy resulted in that Chinese people lack the habits of democracy with weal awareness of laws. Some college students do not know that they have constitutional rights and their subject consciousness is not strong; some college students' understanding of legal rights is biased and merely regard constitutional rights as the single right to vote or to be selected, and they know little about constitutional rights like personal freedom, human dignity shall not be violated and the freedom of speech; most college students have not exercised the constitutional rights. [4]

The Lack of Constitutional Education at Colleges and Universities. For a student, the most contact is the classroom and teaching materials with few contact with the society. And there is only a rough understanding of many constitutional knowledge on textbooks and at classrooms. [5] Due to the course arrangement and limitation of textbooks, teachers can only explain the preliminary knowledge at class and can hardly explain too extensively, so college students' constitutional information is also very incomplete. Although some college students also pay attention to news and get to know some common legal knowledge from some TV programs, it is far from being enough, and there is still a huge gap in terms of both depth and breadth.

\section{The Importance of Cultivating College Students' Constitutional Consciousness}

College students are the backbone of a country's modernization construction shouldering the historical mission of the great rejuvenation of the Chinese nation. It is an inevitable requirement to attach importance to the education of college students' constitutional consciousness to develop the socialist market economy, the demand to build the socialist rule of law and also the need to cultivate college students to become qualified citizens and the current legal education to the youth. [6]

First, the Need to Build a Socialist Country under the Rule of Law. The rule of law in our country is the rule of law of socialism, and our constitution fully embodies the constitutional consciousness of the proletariat and the broad masses of the people. In China, the meaning of the rule of law includes the supremacy of the Constitution and the law, ruling the country according to law, equality before the law and so on. The most important thing is to rule the country according to the law, and the constitutional law is the focus of the rule of law. Therefore, raising the constitutional consciousness of citizens and cultivating the constitutional spirit of citizens is the key and core of realizing the rule of law and building a socialist country under the rule of law. It is the objective requirement of building a socialist country under the rule of law in China, implementing the basic strategy of governing the country according to the law. [7] Contemporary college students are the builders and successors of the cause of socialist modernization, and shoulder the responsibility of governing the country according to law and establishing a socialist country under the rule of law.

Second, the Inevitable Requirement for the Development of a Socialist Market Economy. Constitutional consciousness is a kind of social consciousness and belongs to the superstructure. The economic base determines the nature and development of the superstructure, so the constitutional consciousness is bound to be constrained by the economic base. But consciousness has a relatively independent, and it will have a certain degree of economic basis of the reaction. A good sense of constitutionalism will promote the development of economic fundamentals. Market economy requires the rule of law, the need for the correct guidance of legal rules, and the rule of law is the protection of the market economy. The college students are the builders and successors of the socialist modernization cause, so it is necessary to strengthen the education of college students' constitutional consciousness, cultivate high-quality and high-level laborers for the smooth development of the socialist modernization cause, and cultivate mature and qualified market players. [8]

Third, the Demand to Cultivate College Students into Qualified Citizens. In today's world, the importance of competition in education, science and technology and talent is becoming more and more prominent in the competition of comprehensive national strength. The competition behind these competitions is actually the competition of talents. It can also be said that it is the competition of citizen's quality. The legal quality of college students is the law knowledge, which is a comprehensive embodiment of enhancing legal awareness, complying with legal norms and the ability to apply laws. 
The constitutional consciousness of college students is an important content of the legal quality of college students. Therefore, improving the constitutional consciousness of college students can improve the legal quality of college students. [9] It is an inevitable requirement to improve the legal quality of college students by cultivating college students' constitutional consciousness and perfecting the constitution structure of college students. Only college students have the higher quality, especially with high legal quality, can they adapt to the needs of national and social development and help to improve the country's comprehensive competitiveness.

\section{Ways to Cultivate Contemporary College Students' Constitutional Consciousness}

Constitutional consciousness is not spontaneously formed, but it must be consciously cultivated, so that students can comply with the Constitution, advocate the Constitution and have faith in it, which leads to that the constitutional consciousness truly becomes an indispensable important content of subjective consciousness in college students' healthy personality structure. Constitutional knowledge is the basis for college students to study other laws. To strengthen the education of constitutional knowledge of college students can promote college students' recognition of the constitution and improve the cognitive level of college students, so that students consciously abide by the Constitution and maintain the authority of the Constitution, which is the premise for college students to improve the constitutional consciousness. Only when students have constitutional knowledge can they understand the constitution, understand the spirit and the concept of the constitution, and only when they understand the principles of the constitution, the basic spirit and the idea, can they establish the correct constitutional consciousness and the constitution faith. We need to give full play to the role of classroom as the main channel of constitutional knowledge education for college students, and realize the systematic and scientific education of school law education.

First of all, Increase the Constitutional Education of Colleges and Universities to Improve the Constitutional Awareness of College Students. Strengthening the Constitutional knowledge education of college students is the basis of cultivating college students' constitutional consciousness. Colleges and universities are important positions to cultivate and improve the constitutional consciousness of college students. School education is the basic way to cultivate college students' constitutional consciousness. Strengthening the education of constitutional knowledge of college students can deepen the students' understanding of constitutional knowledge, make up the deficiency of college students' constitutional cognition and makes the students form the constitutional psychology, recognize the constitution of our country, establish the constitutional beliefs and constitutional authority. [10]

Second, Colleges and Universities should Carry out Campus Law Education Activities, Constitutional Knowledge Contest and other Practical Activities. Colleges and universities are the grassroots units of the popularization of law, so colleges and universities should also bear the responsibility of law education activities. The object of popular science is the college students, especially the college students of law majors. To educate college students to establish a sense of constitution, so that students believe the supremacy of the practical implementation of the principle of the Constitution in order to build our country into a real democracy and follow the rule of law in the country, thus improving the awareness of college students on the constitutional knowledge. The school can hold the campus law knowledge contest, legal knowledge contest, campus culture festival, legal publicity exhibition, legal and cultural activities photo exhibition and theme essay contest.

At last, Improve Systems Related to the Constitution and Enhance College Students' Trust in the Constitution. To improve relevant systems of the Constitution is to make the Constitution and relevant legal systems complete, mutually connected and organically coordinated to ensure that solutions to any problems encountered in implementing, abiding and supervising systems related to the Constitution can be found in a complete legal system, which is also a necessary condition for the establishment of the rule of law. China is a country based on statutes, and the complete legal system is conducive to the orderly construction of the socialist country under the rule of law. [11] The constitutional system related to college students is concerned with the system of basic rights protection, 
electoral system, grassroots self-government system, constitutional supervision system, political party system, economic system, people's congress system and spiritual civilization construction. Through the improvement of the relevant constitutional system, students can enhance the sense of trust in the Constitution.

\section{Summary}

The cultivation of contemporary college students' constitutional consciousness is related to not only their own development, but also the progress of China's modernization and future development of the country and the nation. Although college students have mastered the basic contents of constitutional knowledge, because their constitutional concept is obsolete and their understanding of constitutional consciousness' core contents, the functions of Constitution, the implementation and evaluation of Constitution, their constitutional awareness still remains to be further improved. so colleges and universities should attach importance to the cultivation and education of college students' constitutional consciousness and give full play to the autonomy of college students in studying the constitution.

\section{References}

[1] Decision of the Central Committee of the Communist Party of China on Deepening the Reform of Several Major Issues [M]. People's Press, 2013.

[2] Announcement of the Constitution of the People's Republic of China [M]. Law Press. Law Center of Law Press, 2011.

[3] T.Y.Chun, K.Y.Juan: On the Cultivation of College Students' Constitutional Consciousness. Rule of Law and the Society, 2012(05).

[4] C.Ling: On the Cultivation of Contemporary College Students' Constitutional Consciousness, Journal of South China University of Technology (Social Science Edition), 2006(08).

[5] Perfection of Constitutional Interpretation Procedure [N]. L.H.Rui, Z.Y.Na. Shanxi Youth Daily. $2015(016)$

[6] W.FYu: Improve the Constitutional Supervision System and Explanatory Mechanism [N]. Legal Daily. 2014 (003)

[7] Z.Li: The Lack and Cultivation of College Students' Legal Consciousness [D]. Nanjing Normal University, 2006

[8] Z.Q.Fan: The Concept and Path of Constitutional Implementation [J]. Tsinghua law. 2012(06)

[9] Y.F.Ying: On the Constitutional Belief of Chinese Citizens [J]. Journal of Longdong University. 2009(04)

[10]C.Ling: Investigation Report on Constitutional Consciousness of College Students [J]. Academic Exchange and Dynamic, 2004

[11]D.J.Tao: How Can I Get Close to You, Constitution? - Reflections on the Investigation of Constitutional Consciousness of 300 College Students in $[\mathrm{J}]$. Research on Law Education, 2013(3). 